\title{
IMPLEMENTASI METODE SOKRATIK MELALUI LESSON STUDY UNTUK MENINGKATKAN KETERAMPILAN BERPIKIR KRITIS MAHASISWA
}

\author{
Ketut Susiani ${ }^{1}$, Kadek Suranata ${ }^{2}$
}

\begin{abstract}
This article reports the experience of implementing the action research to apply the Socratic dialogue method through lesson study in the lecture of Educational Profession to improve critical thinking skills of the university students. The subject of this action research is 36 students (22 women and I 4 men) in grade VI class B, Department Guidance and Counseling (BK), Faculty of Education, Universitas Pendidikan Ganesha (Undiksha) on academic years 2016/2017. This action research conducted in cycles (reported in three cycles) which is integrated into the activities of lesson study. In every cycle consisted of a plan, action, observation/evaluation and reflection phase. Critical thinking skills are assessed through observation activities in group discussion activities and classes, as well as through student response in solving essay test (on cases analysis), which assessed by a rubric assessment of students critical thinking skills at each end of the course. The results showed that the mean of the critical thinking skills of students at the end of the first cycle is 50 (low), then at the end of the second cycle increased to 65 (average) and at the end of the third cycle increased again to 89 (high). Research also shows that the lesson learned were founded through collaborating and careful observation of the course observer with researchers in identifying strengths and constraints and to produce efforts to improve the implementation of the course to improve the quality of learning.
\end{abstract}

Keywords: Critical Thinking, Lesson Study, Socratic Dialogue.

\section{PENDAHULUAN}

Berpikir kritis (critical thingking) merupakan keterampilan yang penting untuk dikembangkan oleh setiap mahasiswa dalam mempersiapkan diri dalam bersaing sebagai sumber daya manusia yang unggul. Berpikir kritis merupakan bagian dari keterampilan berpikir tinggkat tinggi (higher-order thingking skills), sementara itu, keterampilan berpikir tingkat tinggi merupakan keterampilan yang sangat penting dipersiapkan bagi guru dalam pendidikan di abad 2 I (Collins, 2014). Keterampilan berpikir tingkat tinggi meliputi berpikir kritis, logis, reflektif, metakognitif dan berpikir kreatif. Kemampuan berpikir tingkat tinggi diartikan sebagai kemampuan untuk menganalisis, membandingkan, menyimpulkan, menafsirkan, mengevaluasi, dan mensintesis (King, 2009). Berpikir tingkat tinggi ditandai dengan kemampuan berpikir yang melampaui

\footnotetext{
I Jurusan PGSD Fakultas Ilmu Pendidikan (FIP) Universitas Pendidikan Ganesha, Bali; susiani_ketut0I@gmail.com.

${ }^{2}$ Jurusan Bimbingan dan Konseling Fakultas IImu Pendidikan (FIP) Universitas Pendidikan Ganesha, Bali; sura@konselor.org.
} 
pengamatan dasar terhadap suatu fakta dan hanya menghafal, namun merupakan kemampuan yang terkait dengan kemampuan evaluatif, kreatif dan inovatif. Berpikir tinggkat tinggi banyak dibicarakan sebagai dasar dari suatu pendidikan yang kuat (Paul \& Elder, 2007).

Mahasiswa SI Bimbingan dan Konseling (BK) merupakan mahasiswa yang dipersiapkan untuk menjadi calon tenaga pendidik (konselor sekolah) pada satuan pendidikan atau konselor pada instansi di luar pendidikan. Terkait dengan isu pendidikan di abad 21 , keterampilan berpikir kritis merupakan salah satu keterampilan berpikir yang perlu dikembangkan bagi mahasiswa tersebut untuk mempersiapkan diri dalam menyongsong era globalisasi dan persaingan sumber daya manusia yang semakin kompleks. Keterampilan berpikir kritis yang tinggi dapat membantu mahasiswa dalam mengembangkan wawasan yang tepat dari mengkaji sumber informasi dan pengetahuan serta melaksanakan tugas sebagai konselor.

Hasil sudi awal selama tiga pertemuan perkuliahan mata kuliah Profesi Kependidikan pada mahasiswa semester VI kelas B, Jurusan BK, Fakultas IImu Pendidikan, Universitas Pendidikan Ganesha, tahun ajaran 2016/2017, teridentifikasi keterampilan berpikir kritis mahasiswa yang rendah, terutama dalam merespon isu-isu topik perkuliahan yang dikemukakan. Perkuliahan yang dirancang dengan metode diskusi kelas (classroom discusion) hanya mampu melibatkan keaktifan beberapa mahasiswa untuk terlibat dalam diskusi. Sehingga, perkuliahan selama tiga kali pertemuan tersebut belum secara optimal memfasilitasi mahasiswa untuk mengembangkan keterampilan berpikir kritis terhadap isu-isu atau tema diskusi dalam perkuliahan. Berdasarkan temuan tersebut, dianggap penting untuk merancang dan menerapkan suatu metode perkuliahan yang dapat membantu mengembangkan kemampuan berpikir kitis para mahasiswa tersebut.

Untuk dapat berpikir secara cerdas, kritis, kreatif dan bijaksana seorang pelajar maupun guru membutuhkan kemampuan untuk mengenali masalah dalam pembelajaran di dalam kelas, mendefinisikan masalah tersebut, membuat formulasi strategi yang sesuai untuk mengatasinya. Terdapat banyak strategi dan metode pembelajaran yang dapat diterapkan untuk mengembangkan keterampilan berpikir kritis para mahasiswa atau peserta didik. Salah satunya adalah melalui metode dialog Socrates. Pembelajaran dengan metode Socrates adalah prosedur pembelajaran yang mempunyai sejarah dan prestise panjang 
pada Zaman Yunani awal. Pada awalnya, strategi Socrates diajarkan melalui dialog tanya-jawab untuk membimbing dan memperdalam tingkat pemahaman pebelajar yang berkaitan dengan materi yang diajarkan sehingga pebelajar mendapatkan pemikirannya sendiri dari hasil konflik kognitif yang terpecahkan (Johnson \& Johnson, 2002). Metode pembelajaran dialog Socrates merupakan metode pembelajaran dengan konsep belajar melalui memunculkan pertanyaan demi pertanyaan untuk membangun pengetahuan dan kemampuan berpikir tingkat tingi (higher-order thinking skills) melalui kolaborasi dialog pertanyaan antara peserta didik dengan pendidik serta diantara peserta didik, melalui pesan verbal maupun non-verbal (Suhadi et al., 2016).

Sementara itu, Conklin (2007) menyatakan bahwa dialog Socrates merupakan metode yang sangat baik untuk meningkatkan kemampuan berpikir peserta didik, dimana proses yang berlangsung adalah diskusi intelektual dalam basis konten yang dipelajari. Picciano (2009) juga menyebutkan hal senada, bahwa dialog Socrates merupakan metode pembelajaran melalui memunculkan pertanyaan-pertanyaan untuk membantu pembelajar mengembangkan keterampilan berpikir kritis. Tucker \& Neely (2010) juga menyatakan bahwa dialog Socrates dapat membantu guru memotivasi siswa untuk aktif membahas topik pembelajaran secara kritis, dalam dialog yang menantang pebelajar aktif memikirkan pemecahan masalah terhadap suatu isu yang dikemukakan. Senada dengan itu, Luther (2006) juga mencatat bahwa dialog Socrates mampu mengembangkan kesadaran kritis pebelajar karena mereka dikonfrontasikan dengan kontradiksi ekonomi, politik, dan sosial.

Sementara itu, Paul \& Elder (200I) secara tegas mengemukakan bahwa metode dialog atau pertanyaan Sokrates terkait erat dengan konsep berpikir kritis karena kedua memiliki tujuan akhir yang serupa. Tujuan dari berpikir kritis adalah untuk menetapkan pemikiran secara tegas atau disiplin, sementara metode dialog atau pertanyaan Sokrates berusaha untuk menumbuhkan suara batin, melalui model dan strategi interogasi, dan mendisiplinkan pikiran. Berpikir kritis dikembangkan melalui sistem proses yang digunakan untuk membentuk dan membentuk pemikiran seseorang, dengan fokus pada penalarannya. Dalam metode dialog Socrates, mengajukan pertanyaan yang tepat adalah penting, karena pemikiran yang baik berasal dari pertanyaan yang merangsang pemikiran (Elder \& Paul, 2010). 
Penggunaan metode dialog Socrates juga telah mendapatkan dukungan bukti-bukti dari hasil studi emperik. Koellner-Clark et al. (2002) dan Hajhosseiny (2012) masing-masing menunjukkan bahwa metode dialog Socrates efektif mengembangkan pemikiran kritis peserta didik, serta mengembangkan motivasi dan interaksi kelas yang aktif. Salah satu penelitian yang dilakukan di Indonesia oleh Redhana (20I4) yang menyelidiki perbedaan hasil belajar antara siswa yang belajar dengan model pembelajaran seminar Socrates dan model pembelajaran langsung di SMA Negeri I Gianyar, Bali, menunjukkan bahwa terdapat perbedaan yang signifikan hasil belajar antara siswa yang belajar dengan model pembelajaran seminar Socrates dan siswa yang belajar dengan model pembelajaran langsung. Siswa yang belajar dengan model pembelajaran seminar Socrates menunjukkan hasil lebih tinggi daripada siswa yang belajar dengan model pembelajaran langsung.

Berdasarkan uraian di atas, penelitian ini bertujuan untuk mengetahui peningkatan keterampilan berpikir kritis mahasiswa setelah mengikuti perkuliahan dengan metode dialog Socrates pada mata kuliah profesi Kependidikan. Penerapan metode pembalajaran dialog Socrates dalam penelitian ini akan dirangkaikan dengan kegiatan lesson study (kaji tindak pembelajaran). Pelaksanaan perkuliahan dengan metode dialog Socrates dalam perkuliahan profesi keguruan dalam penelitian ini diobservasi oleh kolega dosen sebagai observer pembelajaran, yang secara berkolaborasi dengan peneliti menganalisis, merefleksi, mengevaluasi pelaksanaan pembelajaran, serta memikirkan solusi perbaikan dari kendala-kendala yang ada dalam kegiatan perkuliahan dengan metode dialog Socrates yang dilaksanakan.

\section{METODE}

Penelitian ini menggunakan rancangan penelitian tindakan. Rancangan penelitian tindakan adalah suatu bentuk penelitian refleksi diri kolektif yang dilakukan dalam praktik pembelajaran di kelas untuk meningkatkan kualitas praktik pembelajaran dan pemahaman terhadap praktik pembelajaran tersebut (Kemmis \& McTaggart, 1988). Penelitian tindakan ini dilakukan secara bersiklus (dalam artikel ini dilaporkan tiga siklus) dimana pada setiap siklus terdiri dari tahap perencanaan, tindakan, observasi/evaluasi dan refleksi (Agung, 2014). Penelitian tindakan ini menggunakan pendekatan kuantitatif dan kualitatif secara terintergrasi. 
Kegiatan penelitian tindakan dalam tiga siklus ini diintergrasikan dengan prinsip komunitas belajar (learning community) dalam bentuk kaji tindak pembelajaran (lesson study), sekelompok pendidik (dosen) merancang, mengamati, mengevaluasi, dan merefleksi kegiatan pembelajaran mereka, secara kolaboratif dan kolegialitas menemukan kelebihan dalam kegiatan pembelajaran serta mendiskusikan solusi dari hambatan yang ditemui dalam menyelenggarakan pembelajaran (Sato, 20I2). Learning community atau juga dikenal dengan lesson study merupakan upaya peningkatan professional guru atau pendidik melalui diskusi rancangan pembelajaran, mengamati pembelajaran dan merefleksi hasil kegiatan pembelajaran (Susilo, 2010). Kegiatan kaji tindak pembelajaran melibatkan lima dosen sebagai observer pembelajaran.

Subjek penelitian ini adalah mahasiswa semester VI kelas B Jurusan BK FIP Undiksha yang mengikuti perkuliahan pada mata kuliah profesi Kependidikan pada semester genap 2016/2017, dengan jumlah 36 mahasiswa. Tiga siklus penelitian tindakan menggunakan metode dialog Socrates ini dilaksanakan pada enam kali pertemuan kuliah profesi keguruan dengan membahas tiga topik/isu, yaitu: (I) etika professional guru, (2) kebijakan peningkatan profesionalitas guru di Indonesia, dan (3) pola sertifikasi guru di Indonesia. Masing-masing topik dibahas dalam dua kali pertemuan kuliah dengan alokasi waktu $2 \times 50$ menit (2 jam pertemuan kuliah).

Target keberhasilan dalam penelitian tindakan ini adalah tercapainya peningkatan keterampilan berpikir kritis mahasiswa minimal pada kriteria tinggi (skor >79). Keterampilan berpikir kritis mahasiswa dinilai berdasarkan hasil observasi aktifitasnya dalam mengikuti diskusi dalam kelompok atau diskusi kelas serta melalui jawaban yang ditulis dari soal essay tentang analisis kasus yang dikerjakan mahasiswa secara individual pada setiap akhir pertemuan kuliah. Penilaian keterampilan berpikir kritis mahasiswa menggunakan rubrik penilaian keterampilan berpikir kritis dalam perkuliahan profesi keguruan yang dikembangkan berdasarkan tiga indikator, meliputi (I) kemampuan menganalisis suatu isu menjadi suatu pertanyaan-pertanyaan atau permasalahan yang menarik, (2) kemampuan melakukan sintesis terhadap permasalahanpermasalahan dan (3) kemampuan menyimpulkan permasalahan, hasil sintesis, menjadi produk pengetahuan yang baru.

Skor yang diperoleh mahasiswa dalam aktifitas diskusi selama perkuliahan dan dalam mengerjakan soal-soal essay berdasarkan rubrik penilaian dirata- 
ratakan menjadi nilai keterampilan berpikir kritis pada akhir setiap siklus (dua kali pertemuan kuliah) dengan rentangan skor 0-100. Data skor keterampilan berpikir kritis dianalisis secara deskrptif kuantitatif, serta dikonversikan dalam penilaian acuan patokan skala lima, skor 0-39 sebagai nilai sangat rendah, 40-64 sebagai nilai rendah, skor 65-79 disebut cukup, skor 80-89 dikategorikan tinggi dan skor 90-100 dikategorikan sebagai nilai sangat tinggi (Agung, 2012). Data hasil pengamatan perkuliaahan yang meliputi aktifitas diskusi mahasiswa dan dialog diskusi, serta interaksi pembelajaran yang terjadi didiskusikan dalam kegiatan refeksi melalui diskusi terfokus (melibatkan tim pengajar dan peserta observer kegiatan lesson study) disajikan secara deskritif narasi sebagai refleksi perkuliahan untuk mendukung data kuantitatif mengenai kelemahan dan kelebihan pembelajaran dan fokus-fokus perbaikan pembelajaran/perkuliahan yang perlu dilakukan pada siklus selanjutnya.

\section{DISKUSI}

Siklus I. Kegiatan siklus I diawali dengan diskusi oleh tim pengajar dalam membahas rancangan dan skenario perkuliahan. Perkuliahan pada siklus I dilaksanakan dalam dua kali pertemuan perkuliahan (masing-masing $2 \times 50$ menit) dengan topik perkuliahan "etika professional guru". Dua kali pertemuan perkuliahan tersebut dirancang menggunakan metode dialog Socrates. Pada pertemuan perkuliahan sebelum siklus I, mahasiswa secara berkelompok (masing-masing berjumlah 6-7 orang) telah ditugaskan untuk menganalisis secara kritis sebuah artikel dari media cetak atau pun online (internet) yang terkait dengan topik peruliahan.

Perkuliahan diawali dengan penyampaian isu tentang etika professional guru dengan beberapa contoh kasus kebijakan dan pelanggaran terhadap etika professional guru yang terjadi di Indonesia. Selanjutya masing-masing kelompok menganalisis tema tersebut bersama kelompoknya berdasarkan artikel yang telah disiapkan masing-masing kelompok mahasiswa. Selanjutnya masing-masing kelompok menyampaikan hasil analisisnya dalam diskusi kelas. Berdasarkan hasil analisis tersebut, dosen menfasilitasi mahasiswa untuk memunculkan topiktopik baru yang terkait dengan tema. Topik-topik yang muncul tersebut dikembangkan menjadi fokus diskusi mahasiswa dalam kelompok, antar kelompok dan diskusi kelas. pada tahap akhir, masing-masing mahasiswa 
diminta untuk menuliskan hasil analisis, sintesis terhadap topik-topik terkait yang telah didiskusikan dan membuat sebuah kesimpulan.

Hasil evaluasi perkuliahan menunjukkan skor rata-rata keterampilan berpikir kritis mahasiswa dari hasil diskusi dan menganalisis suatu kasus dalan soal essay dalam dua pertemuan kuliah diperoleh rata-rata keterampilan berpikir kritis mahasiswa (mean) sebesar 50 (dalam kategori rendah), median 50, nilai tertinggi 58, nilai terendah 42, dan Nilai Modus 50. Skor tersebut menunjukkan bahwa dari dua pertemuan pada siklus I ini belum mencapai target keberhasilan yang ditargetkan. Bahkan dalam siklus ini, tidak ada satupun mahasiswa yang berhasil mencapai nilai kemampuan berpikiri kritis yang ditargetkan.

Refleksi perkuliahan pada siklus I dirangkum dari hasil pengamatan observer perkulihan, tercatat terdapat beberapa kekuatan atau kelebihan serta kelemahan pelaksanaan perkuliahan yang menjadi acuan dalam merancang perkulihan pada siklu II, meliputi: (I) topik atau isu yang di kaji dalam perkuliahan menarik dan kontekstual sehingga sebagian besar mahasiswa menunjukkan antusiasme yang cukup tinggi untuk aktif berdiskusi, (2) sebagian besar mahasiswa sudah memahami peran dan tugasnya dalam kegiatan perkuliahan, namun karena dalam setiap kelompok jumlah anggota yang cukup besar (6-7 orang mahasiswa) menghambat setiap anggota mahasiswa untuk dapat memiliki peluang berpartisipasi dalam diskusi kelas. Pada setiap kelompok, anggota mahasiswa yang aktif dan mendominasi mengemukakan ide dalam diskusi hanya 2-3 orang saja, sementara anggota yang lain lebih banyak sebagai pendengar dan pasif, (3) topik yang muncul dalam tema yang dibahas terlalu banyak, sehingga diskusi kurang terfokus dan menimbulkan kebingungan pada beberapa mahasiswa, (4) ada beberapa mahasiswa atau kelompok mahasiswa yang mendominasi diskusi sehingga menutup peluang bagi mahasiswa/kelompok lain yang ingin mengemukakan idenya. Sehingga perlu dipandu atau dibuat aturan diskusi yang lebih memungkinkan semua mahasiswa/kelompok mendapatkan waktu dan kesempatan yang sama untuk berdiskusi.

Rekomendasi yang menjadi pertimbangan untuk merancang perkuliahan pada siklus II, meliputi: (I) tema yang dipilih dalam perkuliahan adalah tema yang menarik, kekinian (up to date), dan kontekstual terkait dengan profesi keguruan, topik yang disepakati untuk pertemuan perkuliahan siklus II adalah tentang "kebijakan peningkatan profesionalitas guru di Indonesia", (2) dosen pengajar 
menfasilitasi mahasiswa memilih dua atau tiga dari beberapa sub topik (sub tema) yang muncul selama diskusi, sehingga sub tema yang menjadi fokus diskusi terbatas pada dua atau tiga isu yang utama dan paling erat kaitannya dengan tema utama yang dibahas, (3) jumlah anggota pada tiap kelompok kecil dikurangi (dari 6-7 orang pada tiap kelompok menjadi 2-3 orang mahasiswa) dan di bahas uraian tugas masing-masing anggota di awal perkuliahan, (4) sebelum diskusi (dialog) dilakukan, disepakati aturan dan waktu atau kesempatan yang dapat diperoleh dari setiap mahasiswa atau kelompok untuk mengemukakan pendapatnya, sehingga peluang untuk semua mahasiswa mengemukakan pendapat secara merata lebih besar.

Siklus II. Kegiatan siklus II diawali dengan diskusi penyusunan rancangan dan scenario perkuliahan. Perkuliahan pada siklus II dilakukan dua kali pertemuan dengan alokasi waktu sama dengan pertemuan kuliah pada siklus sebelumnya. Perkuliahan dirancang melalui forum diskusi tim pengajar dengan menggunakan metode dialog Socrates dengan mempertimbangkan rekomendasi dari pertemuan perkuliahan siklus I. Masing-masing kelompok mahasiswa telah menyiapkan sebuah artikel dari koran atau media cetak dan/atau online (internet) dengan tema kebijakan peningkatan profesionalitas guru di Indonesia untuk menjadi topik kajian dialog pada perkuliahan.

Hasil evaluasi pada dua pertemuan perkuliahan di siklus II menunjukkan nilai rata-rata (mean) keterampilan berpikir kritis mahasiswa sebesar 65 (dalam kategori cukup), median 67 , nilai tertinggi 75 , nilai terendah 50 , dan nilai modus 67. Pada siklus II ini telah terjadi peningkatan kemampuan berpikir kristis mahasiswa jika dibandingkan dengan siklus I, namun dibandingkan dengan target yang ingin dicapai, nilai rata-rata keterampilan berpikir kritis mahasiswa sebesar 65 masih lebih kecil dari nilai pada kriteria tinggi (>79). Hal ini menunjukkan masih adanya hambatan bagi seluruh mahasiswa peserta kuliah untuk mencapai hasil belajar yang optimal dan mengembangkan keterampilan berpikir kritis seperti yang diharapkan.

Refleksi perkuliahan pada siklus II yang merangkum hasil pengamatan yang dilaporkan para observer perkuliahan, yang meliputi: (I) topik atau tema yang di kaji dalam perkuliahan sudah dipersiapkan mahasiswa sebelum pertemuan perkuliahan, sehingga mahasiswa sudah memahami tentang topik atau isu yang dibahas. Selain itu, topik yang dipilih sudah menarik dan kontekstual yang mendorong antusiasme mahasiswa untuk aktif berdiskusi, (2) kelompok 
mahasiswa sudah membagi peran dan tugasnya dalam kegiatan diskusi kelompok dan kelas, namun dalam kegiatan diskusi, teramati kemampuan berdiskusi antar kelompok kurang seimbang, sehingga diskusi kurang mendalam, (3) semua kelompok/ mahasiswa sudah mendapatkan peluang yang sama untuk mengemukakan pendapat dalam berdiskusi, namun masih ada 7 mahasiswa (sekitar $20 \%$ dari 36 mahasiswa) yang sama sekali belum terlibat dalam diskusi.

Berdasarkan hasil refleksi perkuliahan, beberapa rekomendasi dalam merancang perkuliahan pada siklus III, meliputi: (I) topik atau isu perkuliahan yang menarik menjadi kekuatan dalam perkuliahan dengan metode dialog Socrates ini, sehingga tetap dipertahankan memilih topi menarik yang sedang kekinian. Topik atau tema perkuliahan yang disepakati untuk perkuliahan pada siklus III adalah tentang pola sertifikasi guru di Indonesia, (2) sub topik (sub tema) yang muncul selama diskusi tetap dibatasi pada dua atau tiga isu yang paling berhubungan dengan tema utama yang dibahas, (3) pengelompokkan mahasiswa pada kelompok diskusi (2-3 orang mahasiswa) dilakukan dengan mempertimbangkan kesetaraan kemampuan mahasiswa di tiap kelompok berdasarkan skor evaluasi di siklus I dan II, sehingga dalam tiap kelompok kemampuan mahasiswa hetrogen, diharapkan diskusi kelas lebih seimbang dan pembahasan topik lebih mendalam, dan (4) dosen pengajar mendorong mahasiswa yang belum mau/ enggan terlibat berdiskusi.

Siklus III. Perkulihan siklus III dirancang dalam dua kali pertemuan perkuliahan dengan mengkaji topik "pola sertifikasi guru di Indonesia”. Kegiatan siklus III diawali dengan menyusun rancangan perkuliahan (plan). Rancangan dan skenario perkuliahan dengan metode dialog Socrates disusun dengan memasukkan rekomendasi dari perkuliahan pada siklus-siklus sebelumnya, terutama rekomendasi yang dirangkum pada kegiatan siklus II.

Hasil evaluasi keterampilan berpikir kritis mahasiswa pada siklus III mengalami peningkatan yang sangat berarti dibandingkan dengan siklus-siklus sebelumnya, nilai rata-rata (mean) 89 (kategori tinggi), median 92, nilai tertinggi 92, nilai terendah 83, dan Nilai Modus 92. Nilai rata-rata kemampuan keterampilan berpikir kritis mahasiswa sebesar 89 atau pada kategori tinggi yang dicapai melampaui target keberhasilan tindakan yang ditetapkan ( $>79$ atau kategori tinggi). Secara individual, semua mahasiswa peserta kuliah berhasil mencapai nilai target keberhasilan tindakan yang ditetapkan. Terdapat 19 
mahasiswa dari $36(52,8 \%)$ yang berhasil memperoleh nilai pada kategori sangat tinggi (>89) dan 17 mahasiswa lainnya (47,2\%) mencapai nilai keterampilan berpikir kritis pada kategori tinggi.

Catatan para observer menunjukkan bahwa dalam perkuliahan di siklus III ini interaksi diskusi yang terjadi dalam pembelajaran sangat dinamis, topik yang dibahas dikaji secara mendalam. Jumlah mahasiswa yang terlibat diskusi hamper $100 \%$, karena dosen mendorong semua mahasiswa untuk terlibatdalam diskusi. Refleksi dari perkuliahan pada siklus III yang dirangkum berdasarkan catatan para observer menunjukkan kendala-kendala dalam yang ditemui dalam perkuliahan pada siklus I dan siklus II dapat diselesaikan. Artikel ini hanya melaporkan hasil penelitian terbatas pada tiga siklus penelitian, upaya perbaikan perkuliahan pada mata kuliah profesi keguaruan di kelas ini melalui kegiatan lesson study ini berlanjut dilaksanakan selama satu semester perkuliahan sebagai wujud peningkatan kualitas yang berkelanjutan (continious improvement).

Hasil penelitian tindakan yang berlangsung selama tiga siklus ini menunjukkan bukti emperik bahwa penerapan metode dialog Socrates dalam mata kuliah profesi keguruan efektif meningkatkan keterampilan berpikir kritis mahasiswa. Keterampilan berpikir kritis mahasiswa meningkat pada setiap siklus. Pada siklus I, nilai rata-rata keterampilan berpikir kritis mahasiswa sebesar 50 (rendah), pada siklus II menjadi 65 (cukup) dan nilai rata-rata peningkatan kemampuan berpikir kritia pada siklus III menjadi 89 (tinggi). Indikator berpikir kritis yang diukur dalam penelitian ini meliputi kemampuan analisis, sintesis dan kemampuan membuat kesimpulan. Indikatortersebut diukur melalui observasi terhadap aktivitas mahasiswa dalam berdiskusi, serta hasil evaluasi pada setiap akhir pertemuan perkuliahan melalui soal essay. Rangkuman catatan para observer perkuliahan menunjukkan kualitas interaksi pembelajaran melalui kegiatan diskusi diantara mahasiswa meningkat dari siklus I sampai dengan siklus III. Jumlah mahasiswa yang memperoleh kesempatan berdiskusi juga meningkat menjadi 100\% pada perkuliahan di siklus III.

Peningkatan keterampilan berpikir kritis yang dicapai mahasiswa melalui penerapan metode dialog Socrates dalam perkuliahan profesi keguaruan tersebut tidak terlepas dari upaya dosen dalam memfasilitasi dan mengarahkan interaksi, diskusi mahasiswa dalam kelompok dan diskusi kelas. Dalam perkuliahan dengan menggunakan metode Sokratik ini, dosen berupaya berperan dalam (I) merespon jawaban mahasiswa dengan pertanyaan yang 
lebih luas dan mendalam yang dapat memungkinkan mahasiswa mengembangkan pemikirannya secara lengkap dan mendalam, (2) memahami tentang dasar pemikiran yang disampaikan atau diyakini mahasiswa dalam dialog atau diskusi serta menekankan pada implikasinya melalui pertanyaan lebih lanjut, (3) menyampaikan pernyataan yang tegas sebagai titik hubung terhadap pemikiran lebih lanjut, (4) mengembangkan ide-ide untuk kepentingan pengembangan diskusi selanjutnya, (5) memberikan pemahaman kepada mahasiswa bahwa setiap pemikiran akan utuh bila pemikiran tersebut saling terkait satu sama lain, (6) memberikan pemahaman bahwa semua pertanyaan harus mendasari pertanyaan sebelumnya, dan semua pemikiran harus mendasari pemikiran sebelumnya. Kemampuan-kemampuan tersebut merupakan hal yang wajib dimiliki oleh seorang pendidik (guru atau dosen) sebagai dasar untuk menghidupkan dialog dalam metode dialog Socrates (Johnson \& Johnson, 2002).

Hasil penelitian ini sejalan dengan hasil-hasil penelitian yang melaporkan metode pembelajaran dialog Socrates efektif sebagai pembelajaran aktif yang dapat meningkatkan hasil belajar dan keterampilan berpikir kritis siswa. Koellner-Clark et al. (2002) melaporkan bahwa model pembelajaran dialog Socrates efektif memotivasi siswa dalam mengembangkan logika dan berkomunikasi, serta peningkatan pemahaman terhadap materi yang dipelajari. Sebuah penelitian tindakan yang mengidentifikasi pengaruh metode pengajaran dialogis melalui diskusi kelompok dan dialog Sokrates terhadap keterampilan berpikir kritis dan interaksi sosial mahasiswa bidang penddikan oleh Hajhosseiny (2012) juga melaporkan efektivitas metode pengajaran dialogis melalui metode socrates dalam meningkatkan enam elemen disposisi berpikir kritis (analitis, kematangan kognitif, kepercayaan diri, evaluasi diri, keterbukaan pikiran, mencari kebenaran), dan tujuh unsur interaksi sosial (saling mengenal, persahabatan dan keintiman, kecenderungan untuk melakukan dialog, tanggung jawab, interakasi, dan kekaraban dengan dosen).

Peningkatan keterampilan berpikir kritis mahasiswa selama enam kali pertemuan dalam tiga siklus yang dirancang juga terkait dengan keberhasilan dalam memperbaiki kualitas pembelajaran dan mendorong komunitas belajar yang kuat dalam kelas melalui kegiatan lesson study. Selama enam kali pertemuan perkuliahan dari siklus I, II dan III yang telah dilakukan dalam penelitian ini, banyak diperoleh pembelajaran berharga dari proses perkuliahan 
menggunakan metode dialog Socrates ini. Pembelajaran berharga diperoleh melalui hasil pengamatan yang cermat dari para observer pembelajaran yang berkolaborasi dengan peneliti mengidentifikasi kekuatan-kekuatan dalam pelaksanaan pembelajaran serta upaya perbaikan dari kekurangan-kekurangan serta hambatan yang ada selama pelaksanaan perkuliahan, sehingga kualitas belajar mahasiswa meningkat dari siklus I sampai ke siklus III. Hal ini memberikan bukti emperik bahwa intergrasi kegiatan lesson study dalam pelaksanaan penelitian tindakan, khususnya dengan menerapkan metode pembelajaran dialog Socrates berkontribusi terhadap upaya perbaikan pelaksanaan dan pengeolalan pembelajaran, meningkatkan keterampilan berpikir kritis mahasiswa.

Hasil penelitian ini mendukung hasil-hasil penelitian yang melaporkan bahwa intergrasi kegiatan lesson study dalam pembelajaran berkontribusi positif terhadap upaya peningkatan kualitas pembelajaran, interaksi pembelajaran serta hasil belajar. Prayitno (20I5) melaporkan sebuah penelitian tindakan kelas berbasis lesson study yang menunjukkan bahwa hasil belajar kognitif mahasiswa morfologi tumbuhan melalui penerapan metode pembelajaran STAD berbasis lesson study mengalami peningkatan dari siklus I ke siklus II sebesar I atau I\%. Keterlaksanaan penerapan metode pembelajaran STAD berbasis lesson study berjalan dengan baik karena kualitas pembelajaran yang meningkat dari pembelajaran pada siklus I ke siklus II.

\section{SIMPULAN}

Hasil penelitian ini menyimpulkan bahwa kemampuan metode pembelajaran dialog Socrates melalui lesson study pada mata kuliah Profesi Keguruan efektif meningkatkan keterampilan berpikir kritis mahasiswa semester VI kelas B, Jurusan BK, FIP UNDIKSHA tahun ajaran 2016/20I7. Pada akhir siklus I, nilai rata-rata keterampilan berpikir kritis mahasiswa sebesar 50 (rendah), kemudian pada akhir siklus II meningkat menjadi 65 (cukup) dan pada akhir siklus meningkat menjadi 89 (tinggi). Kualitas interaksi belajar antar mahasiswa melalui diskusi dalam metode dialog Socrates melalui kegiatan lesson study juga mengalami peningkatan dari siklus I sampai dengan siklus III. Pembelajaran berharga (lesson learned) diperoleh melalui hasil pengamatan yang cermat dari para observer pembelajaran yang berkolaborasi dengan peneliti mengidentifikasi kekuatan-kekuatan dalam pelaksanaan pembelajaran serta 
upaya perbaikan dari kekurangan-kekurangan serta hambatan yang ada selama pelaksanaan perkuliahan, sehingga kualitas belajar mahasiswa meningkat.

Bagi para pendidik (guru, dosen, instruktur, dan sebagainya) dalam menggunakan metode dialog Socrates dalam pembelajaran, agar memperhatikan: I) memberikan pertimbangan yang cermat dalam menentukan tema atau isu sebagai bahan diskusi, tema atau isu yang dipilih sebaiknya tema yang up to date (kekinian), menarik, dan kontekstual; 2) topik-topik (sub tema) yang muncul selama diskusi hendaknya dibatasi pada beberapa topik yang utama dari dimensi yang berlawanan terkait tema yang dibahas, sehingga mudah mengarahkan diskusi yang kritis, mendalam dalam kegiatan pembelajaran; 3) jumlah anggota dalam tiap kelompok tidak terlalu banyak (2-3 orang mahasiswa) serta pengelompokan dilakukan secara hetrogen, dengan mempertimbangkan kesetaraan kemampuan mahasiswa di tiap kelompok. Penentuan anggota kelompok secara hetrogen berkaitan dengan diskusi yang lebih seimbang dan pembahasan topik lebih mendalam dan kritis; dan 4) pentingnya ditentukan dandisepakati tugas dari masing-masing anggota dalam tiap kelompok, aturan dalam diskusi, dan regulasi peluang kesempatan masing-masing anggota pada tiap kelompok dalam menyampikan ide dan pendapatnya.

Hasil penelitian ini telah mendukung bukti emperik tentang kontribusi positif mengintergrasikan kegiatan lesson study dalam kegiatan pembelajaran khususnya dalam menyelenggarakan perkuliahan di perguruan tinggi. Kegiatan lesson study juga mengembangkan kemitraan, kolaborasi dan kolegialitas diantara para pendidik (dosen). Dengan demikian, direkomendasikan kepada dosen untuk secara berkelanjutan menyelenggarakan kegiatan lesson study yang dapat juga diintegrasikan dalam pelaksanaan penelitian tindakan, sehingga dosen dapat melakukan upaya perbaikan dalam pelaksanaan pembelajaran/perkuliahan dan bertindak profesional secara berkelanjutan (continious improvement), sekaligus melakukan kajian atau penelitian tentang pengelolaan pembelajaran.

\section{REFERENSI}

Agung, A. A. G. (20I4). Buku ajar metodologi penelitian pendidikan. Malang: Aditya Media Publishing.

Agung, A. A. G. (20I2). Buku ajar evaluasi pendidikan. Singaraja: Undiksha Press.

Collins, R. (20I4). Skills for the 2 Ist century: Teaching higher-order thingking. Curriculum \& Leadership Journal, I2(I4). 
Conklin, H. G. (2007). Methods and the middle: elementary preservice teachers' view in their preparation for teaching Middle School social studies. Research in Middle Level Education, 3I (4), I-I6.

Elder, L., \& Paul, R. (20I0). Critical Thinking Development: A Stage Theory with implications for instruction. [Online]. Tersedia: http://www.criticalthinking.org/articles/ct-development-a-stage-theory... [24 Maret 2015].

Hajhosseiny, M. (2012). The effect of dialogic teaching on students' critical thinking disposition. Procedia-Social and Behavioral Sciences, 69, 13581368. DOI: 10.1016/j.sbspro.2012.12.073.

Johnson, D. W., \& Johnson, R. T. (2002). Meaningful assessment: a manageable and cooperative process. Boston: Allyn and Bacon.

Kemmis, S., \& McTaggart, R. (eds.), ( 1988). The action research planner. Victoria, Australia: Deakin University Press.

King, F. J., Goodson, L., \& Rohani, F. (1998). Higher order thinking skills: Definition, teaching strategies, assessment. Washington DC: The Center for Advancement of Learning and Assessment.

Koellner-Clark, K., Stallings, L. L., \& Hoover, S. A. (2002). Socratic seminars for mathematics. The Mathematic Teacher, 95(9), 682-687.

Luther, J. (2006). I-Searching in context: thinking critically about the research unit. English Journal, 95(4), 68-74.

Paul, R., \& Elder, L. (2007). Critical thinking: The art of Socratic questioning. Journal of Developmental Education, 3I (I), 34-37.

Paul, R., \& Elder, L. (200I). Critical thinking: Tools for taking charge of your learning and your life. Upper Saddle River, NJ: Prentice-Hall.

Picciano, A. G. (2009). Blending with Purpose: The Multimodal Model. Journal of the Research Center for Educational Technology, 5(I), 4-I4.

Prayitno, T. A. (20I5). Penerapan metode pembelajaran Student Teams Achievement Divisions berbasis lesson study untuk meningkatkan hasil belajar kognitif mahasiswa morfologi tumbuhan. Saintifika, 17(2), 10-19.

Redhana, I. W. (20I4). Pengaruh model pembelajaran seminar Socrates terhadap hasil belajar siswa. Cakrawala Pendidikan, 33(I), 27-38.

Sato, M. (20I2). Mereformasi sekolah: Konsep dan praktik komunitas belajar. Tokyo: IDCJ Inc. 